K A N D A I

\begin{tabular}{|l|l|l|}
\hline Volume 15 & No. 1, Mei 2019 & Halaman 13-26 \\
\hline
\end{tabular}

\title{
REPRESENTASI AKSI 212 DI KORAN SINDO DAN MEDIA INDONESIA (Representation of Action 212 in Sindo and Media Indonesia News Paper)
}

\author{
Yusep Ahmadi F. \& Reka Yuda Mahardika \\ Fakultas Pendidikan Bahasa IKIP Siliwangi \\ Jalan Terusan Jendral Sudirman Cimahi \\ Pos-el: yusep-ahmadi-f@ikipsiliwangi.ac.id
}

(Diterima: 26 April 2018; Direvisi: 13 November 2018; Disetujui: 25 Maret 2019)

\begin{abstract}
This paper is the result of critical discourse analysis research on news related to the discourse of Action 212 in Sindo and Media Indonesia newspapers. The purpose of this study isto find out the representation of Action 212 in both media. The method used is qualitative with the Fairclough AWK theory. The results of the text analysis show that Koran Sindo has represented Action 212 in a positive meaning and image. Meanwhile, Media Indonesia represents Action 212 under the domination of Joko Widodo's representation as president who gets appreciation from various circles for his presence in Action 212. At the level of text interpretation, Sindo newspaper is more in favor of Action 212 than Media Indonesia. This is very evident from the title of the news broadcast: the Sindo newspaper gave the title "Supermassa Action, Superdamai" while the Media Indonesia newspaper entitled "The President Praised for Visiting Participants in Action". At the level of explanation, it can be concluded that the representation is in line with the socio-culturalpolitical context underlying the two media. The Sindo newspaper, led by Hary Tanoesudibjo, is known to be close to Islam, as an effort to gain Muslim support for the media business and the Perindo party. Meanwhile, Media Indonesia, which is inseparable from the sociopolitics of Surya Paloh, is a supporter of the government, including supporters of the Ahok governor who is suspected of defaming Islam.
\end{abstract}

Keywords: Wacana Aksi 212, CDA Fairclough model, Koran Sindo, Media Indonesia

Abstrak

Makalah ini merupakan hasil penelitian analisis wacana kritis terhadap pemberitaan yang berkait wacana Aksi 212 di media Koran Sindo dan Media Indonesia. Tujuan penelitian ini adalah untuk mengetahui representasi Aksi 212 di kedua media tersebut. Metode yang digunakan adalah kualitatif dengan teori AWK Fairclough. Hasil analisis teks menunjukkan Koran Sindo telah merepresentasikan Aksi 212 ke dalam makna dan citra yang positif. Sementara itu, Media Indonesia dalam merepresentasikan Aksi 212 dibawah dominasi representasi Joko Widodo sebagai presiden yang mendapatkan apresiasi dari berbagai kalangan atas kehadirannya di Aksi 212. Pada tataran interpretasi teks Koran Sindo lebih berpihak kepada Aksi 212 dibanding Media Indonesia. Hal itu sangat terlihat dari judul berita yang disiarkan: koran Sindo memberikan judul "Aksi Supermassa, Superdamai" sedangkan koran Media Indonesia berjudul "Presiden Banjir Pujian Datangi Peserta Aksi". Pada tataran eksplanasi dapat disimpulkan representasi tersebut sejalan dengan konteks sosiokultural-politik yang melatarbelakangi dua media tersebut. Koran Sindo yang dipimpin Hary Tanoesudibjo dikenal dekat dengan Islam, hal itu sebagai upaya meraih dukungan muslim untuk bisnis media dan partai Perindo. Sementara itu, Media Indonesia yang tidak terlepas dari sosiopolitik Surya Paloh adalah pendukung pemerintah termasuk pendukung gubernur Ahok yang diduga (dikatakan diduga karena pada saat itu Ahok belum terbukti secara hukum menistakan agama Islam) menistakan agama Islam.

Kata-kata kunci: Wacana Aksi 212, AWK model Fairclough, Koran Sindo, Media Indonesia

DOI: $10.26499 / j k . v 15 i 1.728$

How to cite: Ahmadi F., Y. (2019). Representasi aksi 212 di Koran Sindo dan Media Indonesia. Kandai, 15(1), 13-26 (DOI: $10.26499 / j k . v 15 i 1.728$ 


\section{PENDAHULUAN}

Aksi 212 juga dikenal sebagai aksi bela Islam 3 merupakan aksi unjuk rasa sekaligus doa bersama yang dilaksanakan hari Jumat tanggal 2 Desember 2012 di Monas (Monumen Nasional) dan sekitarnya. Aksi ini merupakan aksi lanjutan dari beberapa aksi sebelumnya, yakni aksi bela Islam 1 pada14 Oktober 2016 dan aksi bela Islam 2 pada tanggal 4 November 2016. Aksi-aksi tersebut pada dasarnya merupakan kegiatan unjuk rasa terhadap kasus dugaan penistaan agama yang dilakukan Basuki Cahaya Purnama alias Ahok.

Massa yang melakukan unjuk rasa tersebut menuntut agar Ahok segera diadili dan diproses secara hukum. Sebagaimana dalam konferenesi pers yang dilakukan Gerakan Pengawal Fatwa MUI yang dalam hal ini diwakili oleh Habib Rizieq Shihab sebagai pimpinan menyatakan bahwa Aksi 212 adalah aksi superdamai yang pada intinya aksi lanjutan yang bertujuan agar saudara Ahok diproses secara hukum dan diadili seadil-adilnya. Adapun Aksi 212 tersebut berbentuk doa bersama dan sholat jumat bersama yang di dalamnya terdapat berbagai seruan atau orasi tentang kasus tersebut. Aksi 212 telah menjadi pemberitaan nasional bahkan internasional. Banyaknya perhatian dari masyarakat tersebut tentu membuat Aksi 212 menjadi sebuah wacana yang besar.

Berkait dengan itu, setiap pemberitaan media memiliki kepentingan dan ideologi tertentu dalam merepresentasikan suatu wacana. Sebagaimana yang dikemukakan Fairclough,2003,hlm. 9-10) setiap teks (termasuk pemberitaan media) membawa ideologi untuk kepentingan tertentu. Penelitian ini meneliti apa dan bagaimana Koran Sindo (selanjutnya disebut KS) dan Media Indonesia (selanjutnya disebut MI) merepresentasikan Aksi 212 dalam pemberitaannya.

Penelitian-penelitian terdahulu berkait wacana yang berkaitan dengan
Ahok juga pernah dilakukan penulis Ahmadi (2016) dengan meneliti modalitas ujaran Ahok dalam wacana Kalijodo. Selain itu, dalam kasus lain penelitian mengenai marketing politik Jokowi-Ahok dalam pilkada DKI Jakarta pernah dilakukan Utomo (2013). Sementara itu, kasus-kasus Ahok berkaitan dengan, kasus penistaan agama atau SARA sudah dilakukan beberapa peneliti seperti penelitian Aminuddin (2017) dengan judul "Instagram: Bingkai Kasus Agama di Media Sosial", penelitian Mayasari (2017) dengan judul "Konstruksi Media Terhadap Berita Kasus Penistaan Agama Oleh Basuki Tjahaya Purnam (Ahok)", penelitian Atmaja (2014) berjudul “" Analisis Framing Terhadap Pemberitaan Sosok Basuki Tjahaya Purnama (Ahok) di Media Online”. Penelitian- penelitian tersebut lebih menekankan kasus Ahok yang berkaitan dengan kasus (dugaan) penistaan agama akibat ucapan Ahok yang menyinggung ayat Alquran surat $\mathrm{Al}$ Maidah 21 dan tentang politik Ahok. Akan tetapi, dari kesemua penelitian tersebut belum membahas kasus (dugaan) penistaan Ahok yang berhubungan dengan "Aksi 212". Oleh karena itu, penelitian ini menarik dilakukan dengan harapan hasilnya menambah khazanah ilmu pengetahuan di bidang analisis wacana kritis dan memberi informasi yang jelas dan berimbang kepada masyarakat, serta memberi masukan kepada media agar memberikan pemberitaan yang proporsional. Adapun tujuan penelitian ini adalah untuk mendeskripsikan bentukbentuk kebahasaan yang digunakan KS dan MI dalam merepresentasikan Aksi 212 dan untuk mendeskripsikan proses produksi teks serta latar belakang sosiokultural-politik yang melatarbelakangi kemunculan pemberitaan Aksi 212 di KS dan MI. 


\section{LANDASAN TEORI}

Landasan teori merupakan fondasi penelitian dalam membedah suatu data menjadi hasil temuan penelitian yang objektif dan terarah. Berikut beberapa landasan teori yang menjadi dasar penelitian dan menjadi alat dalam menganalisis dan membahas data.

\section{Analisis Wacana Kritis Model Fairclough}

Analisis wacana kritis model Norman Fairclough didasarkan pada bagaimana menghubungkan teks yang mikro dengan konteks masyarakat yang makro. Fairclough membangun suatu model analisis wacana yang mempunyai kontribusi tidak hanya terhadap ranah linguistik semata melainkan juga terhadap analisis sosial dan budaya, sehingga ia mengombinasikan tradisi analisis tekstual yang selalu melihat bahasa dalam ruang tertutup dengan konteks masyarakat yang lebih luas.

Fairclough (1992) berusaha melahirkan teori sosial bahasa, yaitu dengan menggabungkan kaidah analisis wacana yang berorientasi pada lingustik, pemikiran sosial, dan politik. Dengan memaknakan 'wacana' bersinonim dengan language use (penggunaan bahasa), parole (ujaran), dan performance (pertunjukkan), serta melibatkan bahasa lisan atau tulisan, dan diperluas dengan penggunaan semiotik, seperti fotografi atau komunikasi tanpa ujaran (Fairclough, 1995). Selanjutnya, analisis wacana bagi Fairclough (1995) merupakan analisis bagaimana teks berperan dalam praktik sosial budaya. Fairclough melihat wacana sebagai bentuk praktik sosial dan bukan sebagai aktivitas individu atau menggambarkan suatu situasi saja. Wacana adalah praktik yang bukan sekadar menunjukkan dunia tetapi juga menandakan dunia, membentuk, dan membina dunia dalam makna (Fairclough 1992; 1995; Fairclough \& Wodak 1997).
Secara ringkas, wacana dianalisis pada tiga dimensi: teks (text), praktik wacana (discourse practice), praktik sosial budaya (sosiocultural)

\section{Bagan Kerangka Analisis Tiga Dimensi Fairclough}

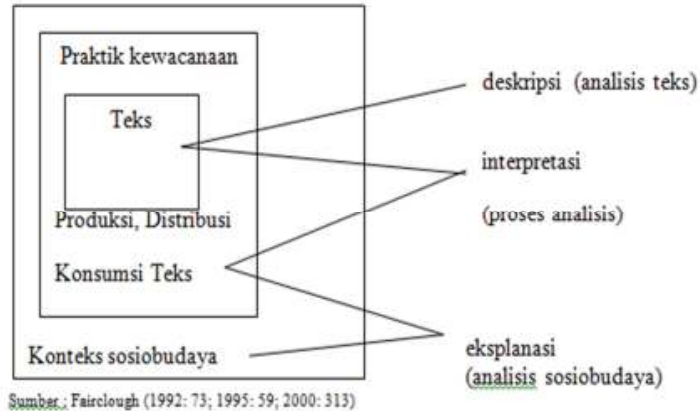

\section{Representasi dan Pemberitaan Media}

Representasi merupakan realitas dunia yang disusun oleh pihak tertentu dan ditujukan kepada pihak tertentu juga. Menurut Santoso (2012) untuk memahami representasi kita harus mengeksplorasi pembentukan makna tekstual yang dipengaruhi oleh dimensi sosial teks. Sejalan dengan itu, menurut Eriyanto (2009) representasi menunjuk pada bagaimana seseorang, satu kelompok, gagasan atau pendapat tertentu ditampilkan dalam pemberitaan. Dengan perkataan lain representasi merupakan pembentukan sesuatu melalui bahasa.

$$
\text { Selanjutnya, Fiske }
$$
menyatakan bahwa wartawan dan perangkat media pada umumnya akan sangat terpengaruh oleh ideologi tertentu dalam memberitakan suatu peristiwa. Ideologi itu dalam pandangan kritis mejadi hal penentu bagaimana suatu peristiwa berikut dengan elemen-elemennya seperti tokoh, gagasan, objek penerima digambarkan. Dengan perkataan lain representasi suatu peristiwa dalam sebuah media tidak terjadi secara "alamiah", tetapi representasi yang dibuat secara terencana, terstruktur dan terorganisasi dengan baik. 


\section{Bahasa dan Analisis Wacana Kritis}

Bahasa adalah sistem lambang bunyi yang arbitrer yang digunakan manusia untuk berkomunikasi. Selain itu, bahasa sebagai sistem lambang merupakan produk sosial karena tanpa adanya konteks sosial tidak akan ada yang namanya bahasa. Sebagaimana yang dikatakan Halliday (1985) bahasa merupakan sistem semiotik sosial. Lebih jauh Santoso (2008) mengatakan bahwa mengkaji bahasa hakikatnya mengkaji teks atau wacana. Hal itu dapat dimaknai bahwa mengkaji bahasa perlu mempertimbangkan konteks sosialnya.

Setakat dengan hal di atas, analisis wacana kritis merupakan sebuah metode atau pendekatan baru dalam penelitian ilmu-ilmu sosial budaya dalam meneliti dan memerikan fenomena-fenomena sosiokultural yang mengandung ketidakadilan, dominasi atau diskriminasi (Haryatmoko, 2016). Dalam penelitian analisis wacana kritis (AWK) tersebut aspek analisis bahasa memerankan peran yang sangat penting karena bahasa sebagai data semiotik wajib ada dalam penelitian AWK. Sebagaimana diungkapkan Fairclough bahwa analisis tataran teks merupakan analisis level pertama dalam meneliti sebuah fenomena wacana sebagai konstruksi semiotika sosial ( Santoso, 2012). Dengan model AWK Fairclough sebuah wacana dapat diketahui ideologinya.

\section{METODE PENELITIAN}

Metode penelitian ini adalah metode kualitatif dengan pendekatan analisis wacana kritis model Fairclough. Analisis wacana kritis model Fairclough adalah metode analisis wacana yang menggabungkan tiga analisis wacana secara terintegrasi, yakni analisis tataran teks, analisis tataran produksi dan konsumsi teks, dan tataran analisis sosiokulturan teks (Ahmadi, 2014, hlm. $254-255$ ). Sumber data adalah berita dengan judul Aksi Supermassa, Superdamai (KS edisi 3 Desember 2016) dan Presiden Banjir Pujian Datangi Peserta Aksi (MI edisi 3 Desember 2016). Teknik pengambilan data dengan teknik purposive sampling. Setiap data yang sudah ditentukan tersebut dianalisis dan dideskripsikan berdasarkan karakteristik data ke dalam pola tertentu.

\section{PEMBAHASAN}

Analisis tekstual adalah analisis tahap pertama dalam AWK model Fairclough. Dimensi tekstual atau dimensi mikro ini dianalisis dengan beberapa perincian. Menurut Fairclough (1992) ada empat bentuk atau sifat teks yang dapat dianalisis, yaitu struktur teks, koherensi teks, tata bahasa, dan leksikal. Namun, dalam penelitian ini hanya akan membahas struktur teks, ketransitifan, dan modalitas.

\section{Struktur Teks}

Dalam banyak penelitian struktur teks yang dibahas dalam analisis wacana kritis model Fairclough adalah peninjauan terhadap posisi-posisi substantif yang terdapat dalam bagian-bagian teks. Sebagaimana penelitian Darmayanti dkk. (2011) ataupun Ahmadi F. (2014) yang membagi struktur teks menjadi tiga bagian: pembuka, isi, dan penutup. Dalam penelitian ini selain akan meihat struktur bagian pembuka, isi, dan penutup juga akan menilai jumlah kata. Besar kecil jumlah kata pemberitaan dapat dimaknai sebagai besar tidaknya perhatian media terhadap peristiwa (wacana) tersebut.

Tabel 1

Hasil Temuan Struktur Teks

\begin{tabular}{l|l|l}
\hline \multicolumn{1}{c|}{ Struktur Teks } & \multicolumn{1}{|c}{ KS } & \multicolumn{1}{c}{ MI } \\
\hline Judul & Aksi Supermassa, Superdamai & $\begin{array}{l}\text { Presiden Banjir Pujian Datangi } \\
\text { Peserta Aksi }\end{array}$ \\
\hline Bagian Awal & Representasi Islam & Representasi Joko Widodo \\
\hline
\end{tabular}




\begin{tabular}{l|l|l}
\hline Bagian Isi & Representasi Aksi 212 & $\begin{array}{l}\text { Representasi Aksi 212 dan Joko } \\
\text { Widodo }\end{array}$ \\
\hline Bagian Penutup & Representasi Jokowi dan Jusuf Kalla & Representasi Joko Widodo \\
\hline Jumlah Kata & 617 & 286 \\
\hline
\end{tabular}

Hasil temuan di atas menunjukkan bahwa perhatian KS lebih besar dibanding MI dalam memberitakan Aksi 212. MI cenderung lebih menitikberatkan pada representasi kehadiran Joko Widodo dalam Aksi 212.

\section{Ketransitifan}

Dalam analisis ketransitifan ini disajikan berbagai data ketransitifan yang mengandung tendensi ideologis. Tendensi tersebut dilihat dari hubungan aktor (agen) dengan proses tindakan atau proses mental; hubungan proses tindakan/proses mental dengan tujuan, hubungan aktor dengan tujuan, maupun hubunganhubungan antara ketiganya (hubungan aktor, proses tindakan, dan tujuan)

Tabel 2

Hasil Temuan Data Ketransitifan

\begin{tabular}{|c|c|c|}
\hline \multirow{2}{*}{ No } & \multicolumn{2}{|c|}{ Data Ketransitifan } \\
\hline & KS & MI \\
\hline 1 & $\begin{array}{l}\text { Umat Islam berhasil menunjukkan dirinya cinta } \\
\text { damai }\end{array}$ & $\begin{array}{l}\text { Kedatangan Jokowi berpayung biru dengan } \\
\text { didampingi Wakil Presiden Jusuf Kalla dan } \\
\text { sejumlah pembantunya, mengejutkan peserta } \\
\text { aksi karena di luar agenda aksi }\end{array}$ \\
\hline 2 & $\begin{array}{l}\text { Aksi yang melibatkan jutaan manusia tersebut } \\
\text { berlangsung tertib dan aman hingga acara } \\
\text { berakhir. }\end{array}$ & $\begin{array}{l}\text { Saat meninjau proyek renovasi kawasan Gelora } \\
\text { Bung Karno pagi harinya, Presiden juga } \\
\text { mengaku tidak tahu akan jumatan di mana }\end{array}$ \\
\hline 3 & $\begin{array}{l}\text { Massa juga tidak menyisakan sampah atau } \\
\text { kerusakan tanaman seperti dikhawatirkan }\end{array}$ & $\begin{array}{l}\text { Syekh Ali Jaber sempat melafazkan kunut } \\
\text { nazilah sehingga membuat jemaah banyak } \\
\text { yang menangis }\end{array}$ \\
\hline 4 & $\begin{array}{l}\text { Di sisi lain, aksi yang dikenal dengan Aksi } 212 \text { ini } \\
\text { menjadi ajang unjuk persaudaraan sesama muslim. }\end{array}$ & $\begin{array}{l}\text { Ketua umum Partai Gerindra Prabowo Subianto } \\
\text { mengapresiasi sikap presiden menyapa } \\
\text { peserta aksi }\end{array}$ \\
\hline 5 & $\begin{array}{l}\text { Aksi terbesar dalam sejarah bangsa Indonesia pun } \\
\text { pantas dinobatkan sebagai aksi superdamai. }\end{array}$ & \\
\hline 6 & $\begin{array}{l}\text { Apresiasi juga disampaikan Kapolri Jenderal } \\
\text { Polisi TitoKarnavian atas aksi bela Islam III } \\
\text { berjalan dengan aman dan tidak ricuh. }\end{array}$ & \\
\hline 7 & $\begin{array}{l}\text {... sejumlah pemuka agama yang tampil di podium } \\
\text { kembali menegaskan aksi digelar hanya untuk } \\
\text { menuntut adanya penegakan hukum terhadap } \\
\text { penistaan agama. }\end{array}$ & \\
\hline 8 & $\begin{array}{l}\text { Mereka juga menegaskan digelar tanpa campur } \\
\text { tangan kekuatan politik mana pun... }\end{array}$ & \\
\hline 9 & $\begin{array}{l}\text { Animo massa untuk bergabung dalam Aksi } 212 \\
\text { terbilang sangat luar biasa. }\end{array}$ & \\
\hline 10 & $\begin{array}{l}\text { Mereka datang ke Jakarta untuk membela } \\
\text { Alquran dan menyampaikan aspirasi mengenai } \\
\text { penegakan hukum... }\end{array}$ & \\
\hline
\end{tabular}




\section{Pembahasan Data Ketransitifan}

Pada data $1 \mathrm{KS}$, umat Islam direpresentasikan sebagai aktor yang melakukan aksi cinta damai dan hal itu berhasil dilakukan. Cinta damai dapat dinilai sebagai tujuan/goal dalam kalimat tersebut, dengan demikian umat Islam direpresentasikan positif. Pada data $2 \mathrm{KS}$ hadir ketransitifan berlangsung yang merepresentasikan aktor bertindak tertib. Sementara itu, data $3 \mathrm{KS}$ terdapat bentuk ketransitifan tidak menyisakan yang secara fungsional menjelaskan aktor yang bertindak bersih dengan tidak menyisakan sampah. Sementara itu, pada data 4 dan data $5 \mathrm{KS}$ subjek dari pembicaraannya adalah kegiatan Aksi 212. Hal itu ditunjukkan dengan bentuk ketransitifan menjadi ajang yang menggambarkan bahawa Aksi 212 atau kegiatan bela Islam 3 tersebut menjadi ajang persaudaraan. Secara fungsional Aksi 212 tersebut ditetapkan sebagai aktor yang membuat sesuatu, yakni ajang persaudaraan. Ajang persaudaraan tersebut dapat dinyatakan sebagai bentuk tujuan pada data 4 .

Sejalan dengan data $4 \mathrm{KS}$, tipe data 5 KS juga menempatkan Aksi 212 sebagai aktor yang membuat sejarah atau rekor kegiatan yang dihadiri banyak partisipan dan berlangsung sangat damai. Pada data 6 tampak bentuk ketransitifan disampaikan, dalam data tersebut menempatkan Kapolri sebagai aktor yang menyampaikan apresiasi terhadap Aksi 212 yang berjalan aman dan tidak ricuh. Berbeda dengan data $6 \mathrm{KS}$, data $7 \mathrm{KS}$ menampilkan pemuka agama sebagai aktor yang mengatakan bahwa Aksi 212 merupakan peristiwa atau kegiatan yang semata-mata untuk menuntut penegakan hukum. Melalui kalimat yang terdapat dalam data $7, \mathrm{KS}$ merepresentasikan Aksi 212 sebagai peristiwa penuntutan penegakkan hukum. Kemudian, pada data 8 juga tampak representasi tentang peristiwa Aksi 212 yang bebas dari campur tangan kepentingan politik. Hal tersebut ditegaskan para peserta dalam Aksi 212. Dengan demikian dapat dimaknai bahwa KS dalam memberitakan Aksi 212 dalam citra yang bebas dari politik dan murni sebagai aksi unjuk rasa yang menuntuk penegakkan hukum terhadap kasus dugaan penistaan agama.

Data $9 \mathrm{KS}$ dan $10 \mathrm{KS}$ tampak muncul aktor yang sama, yakni peserta Aksi 212. Proses tindakan dan tujuan yang dimunculkan pada data-data tersebut adalah proses tindakan bergabung, membela, menunjukkan, dan mendengarkan. Dari keempat bentuk ketransitifan tersebut tiga di antaranya berbentuk aktif transitif yang secara fungsional objek dan tujuannya bermakna positif, yakni Alquran, keseriusannya, dan khotbah. Adapun bentuk bergabung secara ketransitifan tidak memiliki objek, tetapi secara makna merepresentasikan Aksi 212 sebagai aksi yang banyak sekali pesertanya.

Dalam MI ditemukan 4 data ketransitifan, pada data 1 MI bentuk ...mengejutkan... merepresentasikan kehadiran Joko Widodo dan rombongan membuat peserta Aksi 212 terkejut. Data 2 MI ...mengaku tidak tahu...merepresentasikan bahwa kehadiran Joko Widodo di Aksi 212 adalah sesuatu yang tidak terencana. Selain itu, data $3 \mathrm{MI}$ merepresentasikan keadaan peserta aksi yang menangis saat Syek Ali Jaber melafazkan kunut, sedangkan pada data 4, MI merepresentasikan Joko Widodo sebagai presiden yang mendapat apresiasi dari Prabowo Subianto. Dapat disimpulkan tiga (data 1, 2, 4) dari empat data ketransitifan yang ada di MI adalah ketransitifan yang merepresentasikan Joko Widodo ke dalam bentuk citra yang netral pada data 1 dan 2, dan citra positif pada data 4. Berlainan dengan tiga data sebelumnya pada data 3 terdapat representasi Aksi 212 dalam citra yang positif.

Berdasarkan pembahasan data ketransitifan di atas dapat ditarik simpulan 
sebagai berikut. Sepuluh data ketransitifan yang dimunculkan KS merepresentasikan peristiwa Aksi 212 sebagai peristiwa yang cinta damai, aman, tertib, dan diapresiasi (citra positif). Berkait dengan itu, penelitian Ahmadi F (2013) juga mengungkapan bahwa melalui analisis ketransitifan dapat diketahui representasi suatu peristiwa. Penelitian Ahmadi F (2013) meneliti representasi kontes Miss World 2013 yang dimunculkan media Sindonews.com. Terdapat kesamaan antara media KS dan Sindonews.com dalam hal keberpihakannnya terhadap peristiwa yang diberitakannya, yakni dimanfaatkannya fitur linguistik ketransitifan dalm membangun citra positif sebuah berita (wacana). Analisis ketransitifan atau struktur juga pernah dilakukan Mayasari dkk. (2013) pada pemberitaan "Saweran untuk Gedung KPK" di MI. Penelitian tersebut mengungkapkan bahwa MI secara ketransitifan atau struktur kalimat memihak KPK dan memberi citra negatif kepada institusi DPR.

Sementara itu, hasil analisis ketransitifan di MI menunjukkan bahwa tiga dari empat data merepresetasikan Presiden Joko Widodo, baik ke dalam citra positif (data 4) maupun citra netral (data 1,2). Kemudian, satu data merepresentasikan Aksi 212 ke dalam citra positif. Melaui analisis ketransitifan tersebut terlihat bahwa KS lebih berpihak terhadap Aksi 212 dibanding MI. Hal tersebut sejalan dengan judul berita KS dan MI, KS mengedepankan Aksi 212 dan MI mengetengahkan kehadiran Joko Widodo di Aksi 212.

\section{Modalitas}

Tabel 3

Hasil Temuan Data Modalitas

\begin{tabular}{|c|c|c|}
\hline \multirow[t]{2}{*}{ No } & \multicolumn{2}{|c|}{ Data Modalitas } \\
\hline & $\mathrm{KS}$ & MI \\
\hline 1 & $\begin{array}{l}\text { "Jadi alhamdulillah peserta kegiatan juga } \\
\text { semua kembali dalam keadaan yang baik } \\
\text { dan saya berpesan dan saya doakan, } \\
\text { kembali selamat di tempat masing-masing } \\
\text {....jalan, "Ujar Tito. }\end{array}$ & $\begin{array}{l}\text { Ketika mantan Gubernur DKI itu menembus lautan } \\
\text { manusia di Monas, Takbir pun menggema menyabutnya, } \\
\text { "Allahu Akbar!” }\end{array}$ \\
\hline 2 & $\begin{array}{l}\text {.Subhanallah, kita merasakan betapa } \\
\text { indahnya Islam, kita merasakan } \\
\text { bagaimana suasana hari ini seperti suasana } \\
\text { kita menjalankan haji di padang Arafah," } \\
\text { papar Tito ... }\end{array}$ & $\begin{array}{l}\text { "Saya ingin memberikan penghargaan setinggi-tingginya } \\
\text { kepada jemaah yang hadir dalam ketertiban sehingga } \\
\text { semuanya terlaksana dengan baik. Allahu Akbar, Allahu } \\
\text { Akbar, Allahu Akbar, "kata presiden sambil } \\
\text { mengepalkan tangan. }\end{array}$ \\
\hline 3 & $\begin{array}{l}\text {... aksi digelar hanya untuk menuntut } \\
\text { adanya penegakan hukum terhadap } \\
\text { penistaan agama. }\end{array}$ & $\begin{array}{l}\text { Kepala negara juga mengucapkan terima kasih atas doa } \\
\text { jemaah. "terima kasih atas doa dan zikir yang telah } \\
\text { dipanjatkan untuk keselamatan bangsa dan negara kita } \\
\text { Allahu Akbar, Allahu Akbar, Allahu Akbar," ucapnya. }\end{array}$ \\
\hline 4 & $\begin{array}{l}\text { Mereka datang ke Jakarta untuk membela } \\
\text { Alquran dan menyampaikan aspirasi } \\
\text { mengenai penegakan hukum ... }\end{array}$ & $\begin{array}{l}\text { Ketua umum Partai Gerindra Prabowo Subianto } \\
\text { mengapresiasi sikap presiden menyapa peserta aksi. } \\
\text { "saya kira itu bagus sekali... }\end{array}$ \\
\hline 5 & $\begin{array}{l}\text { "Hujan ini menjadi berkah buat kami," } \\
\text { tutur Joko, 29, seorang pendemo asal } \\
\text { Purwokerto, Jawa Tengah. }\end{array}$ & "Kita merasakan betapa indahnya Islam" ujar Tito. \\
\hline 6 & & $\begin{array}{l}\text { Presiden dinilai sebagai sosok yang bernyali. 'GENTLE } \\
\text { President,,, e proud of you mr@jokowi', tulis akun } \\
\text { aDIRA 0302, }\end{array}$ \\
\hline
\end{tabular}




\section{Pembahasan Data Modalitas}

Pada analisis modalitas ditemukan lima data modalitas pada KS dan tujuh pada MI. KS memunculkan modalitas dari empat aktor. Modalitas data $1 \mathrm{KS}$ dan data $2 \mathrm{KS}$ diutarakan oleh Tito Karnavian sebagai Kapolri, modalitas yang muncul adalah kesyukuran dan kekaguman terhadap Aksi 212. Hal itu ditunjukkan oleh bentuk modalitas alhamdulillah dansubhanallah. Dua bentuk modalitas tersebut dapat dikategorikan sebagai modalitas ekspresif kekaguman. Dalam istilah Fairclough (dalam Ahmadi F, 2016, hlm. 71) modalitas ekspresif merupakan sikap penutur dalam kaitannya dengan representasi realitas. Kemudian data 3 KS dan data $4 \mathrm{KS}$ merupakan data modalitas yang tidak secara langsung diutarakan penutur. Akan tetapi, secara tidak langsung data $3 \mathrm{KS}$ memuncukan aktor pemuka agama yang direpresentasikan memliki sikap keinginan terhadap penegakan hukum, seperti tersirat dalam frasa hanya untuk menuntut. Selain itu, data 4 memunculkan aktor peserta aksi. Sebagaimana dalam data $3 \mathrm{KS}$, pada data 4 KS tersebut secara implisit menunjukkan sikap keinginan, yakni keinginan penegakan hukum terhadap penista agama dilaksanakan oleh penegak hukum. Modalitas deontik keinginan menurut Alwi (1994) (dalam Ahmadi,2016 hlm. 72 - 73) adalah kewenangan seseorang terhadap suatu realitas berdasarkan kaidah sosial. Jadi, secara sosial peserta aksi tersebut tergerak hatinya untuk menuntuk keadilan hukum atas dugaan penistaan terhadap agamanya. Kemudian data 5 KS terdapat modalitas ekspresif kesyukuran terhadap realitas kegiatan aksi yang diguyur hujan. Modalitas ekspresif kesyukuran diutarakan seorang pendemo yang mengikuti kegiatan Aksi 212 yang pada momen itu diguyur hujan.
Dapat disimpulkan dua dari lima data modalitas yang hadir dalam KS adalah modalitas ekspresif yang bersifat kekaguman dan kesyukuran. Hal tersebut dapat dimaknai bahwa KS merepresentasikan kegiatan Aksi 212 disikapi secara positif oleh semua peserta aksi. Di samping itu, data 3, 4, dan $5 \mathrm{KS}$ adalah modalitas relasional keinginan dan relasional kepastian. Ditinjau dari aktor yang dimunculkan dalam pembentukan modalitas, tidak ada sikap presiden terhadap aksi 212 satu pun yang dihadirkan dalam pemberitaan KS.

Hal ini, sangat berbeda dengan modalitas yang dihadirkan MI yang banyak berkaitan dengan realitas kehadiran Jokowi pada Aksi 212 dan bukan modalitas yang menyikapi realitas peristiwa Aksi 212. Hal itu, sejalan dengan judul pemberitaannya. Berikut di bawah ini pembahasan data modalitas MI.

Data 1 MI terdapat bentuk modalitas Allahu Akbar yang dituturkan para peserta aksi ketika kedatangan Presiden Joko Widodo. Hal itu menunjukkan bahwa kedatangan presiden disambut dengan suka cita. Pada data 2 terdapat modalitas keinginan yang disampaikan presiden, yakni keinginan memberikan apresiasi terhadap Aksi 212. Selain itu, pada data 2 juga ditemukan modalitas Allahu Akbar sebanyak tiga kali yang dimaknai sebagai kekaguman presiden terhadap Aksi 212. Kemudian Presiden RI juga pada data 3 menuturkan sikap terima kasih kepada para peserta Aksi 212 yang telah memberikan doa untuk kebaikan bangsa dan negara Indonesia. Bentukbentuk modalitas yang disampaikan presiden menunjukkan sikap yang positif terhadap peristiwa Aksi 212.

Selanjutnya, pada data 4 dan 5 , data modalitas tersebut merupakan modalitas yang dituturkan oleh Prabowo 
Subianto yang mengapresiasi sikap Joko Widodo berkait kedatangannya ke Aksi 212. Selain itu, modalitas yang berbentuk ekspresif apresiatif juga dihadirkan MI, yakni dengan memunculkan kutipan dari netizen twitter yang secara langsung merepresentasikan sikap apresiatif terhadap Presiden Joko Widodo seperti pada data 5 .

Jadi, modalitas yang ada dalam pemberitaan MI merupakan modalitas ekspresif kekaguman yang memberi citra positif terhadap aksi 212, kemudian modalitas yang menyatakan sikap terima kasih kepada aksi 212 serta modalitas yang menggambarkan sikap apresiatif terhadap Presiden Joko Widodo yang datang ke Aksi 212.

Hasil analisis modalitas dapat disimpulkan menjadi beberapa poin sebagai berikut.

Pertama, ditinjau dari aktor yang hadir dalam pemberitaan, KS menghadirkan tiga aktor, yakni Kapolri Tito Karnavian, pemuka agama, dan peserta aksi sedangkan pada MI memunculkan empat aktor, yaitu Joko Widodo sebagai Presiden, Prabowo Subianto sebagai Ketua Umum Partai Gerindra, Kapolri Tito Karnavian, dan dua netizen.

Kedua, ditinjau dari realitas yang dihadirkan dan disikapi (modalitas) terdapat hal yang berbeda. Pada KS realitas yang dihadirkan adalah hanya terpaku kepada peristiwa Aksi 212 baik dilihat dari segi keamanan, ketertiban, cara peserta aksi berkumpul, maupun keadaan alam ketika peristiwa Aksi 212 berlangsung. Sementara itu, pemberitaan MI menghadirkan realitas kedatangan Presiden Joko Widodo ke Aksi 212 yang diperspektifkan sebagai peristiwa yang tidak kalah penting dibanding Aksi 212 secara keseluruhan. Hal tersebut ditunjukkan oleh tiga modalitas (data $1,2,3$ ) yang merepresentasikan apresiasi terhadap Joko Widodo. Berlainan dengan itu, dalam pemberitaan KS sebaliknya, kedatangan Presdiden Joko Widodo diperspektifkan sebagai sebuah bagian kecil dari perisitiwa Aksi 212. Hal tersebut dibuktikan dengan tidak ditemukannya data modalitas yang menyikapi realitas kedatangan Presiden Joko Widodo di pemberitaan KS.

\section{Pembahasan Praktik Wacana}

Setiap wacana diproduksi oleh seseorang atau suatu kelompok dengan latar belakang dan tujuan tertentu. Wacana berita tentu diproduksi dan disusun oleh perangkat media mulai dari wartawan, editor hingga kepala redaksi media. KS merupakan koran yang berafiliasi dengan MNC Group yang dipimpin Hary Tanoesudibjo. Hary Tanoesudibjo merupakan pengusaha yang dapat dikatakan cukup berpengaruh di Indonesia saat ini terutama di bidang media. Dalam hal ini Hary Tanoesudibjo bisa dikatakan sebagai "the principal" dari media KS dan segala bentuk produksi wacana berita KS dipengaruhi oleh ideologinya. Keberpihakan pemberitaan KS terhadap Aksi 212 sebagaimana hasil temuan analisis teks, menunjukkan bahwa Hary Tanoesudibjo memberi dukungan dan apresiasi terhadap Aksi 212. Sementara itu, alasan mengapa Hary Tanoesudibjo berpihak terhadap Aksi 212 dapat dijawab oleh analisis sosiokultural pada level makro yang akan dibahas di bagian analisis selanjutnya. Kemudian berkaitan dengan konsumsi teks, pemberitaan KS dapat dikonsumsi oleh masyarakat Indonesia secara umum khususnya di kota-kota besar.

Di lain pihak, produksi teks MI tidak lepas dari sang pemimpin Media Group. MI didirikan oleh Teukeu Yousli Syah bersama Surya Paloh (Sumber:http://mediaindonesia.com/abo 
ut-us). Akan tetapi, secara sosiopolitik Surya Paloh lebih berpengaruh dan populer. Secara ideologi Surya Paloh dan Hary Tanoesudibyo memiliki perbedaan. Hal itu ditunjukkan dengan perbedaan partai politik yang dipimpinnya. Pada tahun 2014 Hary Tanoesudibjo mendukung capres Prabowo dan dekat dengan kalangan pesantren sedangkan Surya Paloh merupakan sosok yang mendukung penuh pemerintahan Jokowi. Sejalan dengan itu, redaksi dari pemberitaan aksi 212 di MI dipengaruhi oleh politik kepemimpinan Surya Paloh dengan partai Nasional Demokrat. Ditinjau dari proses konsumsi dapat dibaca secara nasional khususnya kota-kota besar.

Peran bahasa dalam peristiwa tersebut adalah sebagai alat pelancaran ideologi dari kelompok-kelompok yang terlibat. Kelompok aksi 212 lebih berpandangan bahwasannya apa yang telah diungkapkan Ahok pada sebuah pertemuan dengan warga tersebut merupakan tindak penistaan agama terhadap Islam. Oleh karena itu, perlu ditindak secara hukum. Sementara itu, Presiden Jokowi yang terepresentasi lewat pemberitaan MI direpresentasikan sebagai sosok pemimpin yang mengayomi masyarakatnya yakni terlihat dari kedatangan dan sapaan presiden pada Aksi 212.

\section{Pembahasan Sosiokultural-politik}

Situasi negara pada saat terjadinya Aksi 212 adalah sedang adanya pergolakan politik terutama politik di tataran provinsi DKI Jakarta. Tidak hanya masyarakat DKI Jakarta namun secara nasional masyarakat selalu menyoroti kepemimpinan Ahok di Jakarta baik bersikap pro maupun kontra. Latar belakang sosiokulturalpolitik pemeberitaan Aksi 212 di KS dan MI tidak dapat dipisahkan dengan latar belakang para pemimpin media tersebut. Sebagaimana disinggung di muka, KS sebagai media yang berafiliasi dengan MNC Group dipengaruhi oleh latar belakang Hary Tanoesudibjo. Hary Tanoesudibjo dalam konteks sosiopolitik Indonesia kini diperhitungkan. Pada saat pilpres 2014 dia sempat menjadi bakal calon wakil presiden dari partai Hanura, tetapi pada akhirnya gagal dan berpisah dengan partai Hanura. Kini Hary Tanoesudibjo memiliki partai sendiri dengan nama Partai Persatuan Indonesia (Perindo). Perindo memliki visi "mewujudkan Indonesia yang berkemajuan, bersatu, adil, makmur, sejahtera, berdaulat, bermartabat, dan berbudaya"(Sumber:https://partaiperindo .com/?page id=6). Dengan keberpihakan KS dalam merepresentasikan Aksi 212 dapat dimaknai sebagai upaya Hary Tanoesudibjo memperoleh simpati dan dukungan dari jutaan peserta Aksi 212 dan umat Islam Indonesia untuk Perindo dan MNC group yang dipimpinnya.

Berbeda dengan KS, MI sebagai koran nasional dalam pemberitaannya sangat dipengaruhi oleh latar belakang sosiopolitik Surya Paloh selaku pemimpin media tersebut. Surya Paloh merupakan tokoh politik senior di Indonesia, sebelum mendirikan partai Nasional Demokrat Surya Paloh merupakan politisi partai Golkar. Dalam konteks sosiopolitik saat ini Surya Paloh dan partainya merupakan bagian dari koalisi pendukung pemerintah, sedangkan Aksi 212 yang pada intinya merupakan aksi penuntutan penegakkan hukum terhadap kasus dugaan penistaan agama yang diduga dilakukan Basuki Cahaya Purnama (Ahok) yang notabene Ahok merupakan calon gubernur DKI Jakarta yang diusung Partai Nasdem yang dipimpin Surya Paloh.

Oleh karena itu, hal yang logis ketika pemberitaan KS yang memihak terhadap Aksi 212 karena Hary 
Tanoesudibjo ingin mendapat simpati/dukungan dari pembaca Aksi 212 dan muslim. Dengan begitu Perindo yang dipimpinnya juga akan mendapat dukungan atau simpati dari umat Islam Indonesia. Sementara itu, MI tidak memiliki keberpihakan sebesar pemberitaan KS disebabkan karena MI yang dipimpin Surya Paloh merupakan pengusung Ahok sebagai calong gubernur DKI Jakarta 2017.

Berdasarkan pembahasan tataran tekstual, praktik wacana, dan sosiokultural-politik dapat diambil simpulan bahwa Koran Sindo (KS) dan Media Indonesia (MI) membawa ideologi dan pesan yang berbeda terkait peristiwa aksi 212. Hal itu pun tidak terlepas dari latar belakang ideologi sosiokultural-politik pada setiap media masing masing. sebagaimana yang diungkapkan Van Dijk (1998) bahwa ideologi sebagai representasi sosial dasar dari kelompok sosial. Hal itu menandakan ideologi menetukan sikap suatu kelompok.

Kepentingan media KS dalam memberitakan Aksi 212 tersebut adalah untuk menarik simpati dan dukungan pemiliknya Hary Tanoesudibjo yang akan ikut dalam kontestasi politik 2019. Sementara itu, Media Indonesia yang lebih memfokuskan pada kehadiran Jokowi di Aksi 212 tidak terlepas dari sikap pemiliki MI yang konsisten mendukung pemerintahan Jokowi dan senantiasa merepresentasikan Jokowi dalan citra yang positif.

\section{PENUTUP}

Berdasarkan hasil pembahasan tataran tekstual ditemukan 12 data ketransitifan di KS dan 4 di MI. Selain itu, terdapat 5 data modalitas di KS dan 7 di Media Indonesia. Berdasarkan analisis data ketransitifan, Koran Sindo lebih memihak kepada aksi 212 dibanding Media Indonesia. Sementara itu, data modalitas KS juga merepresentasikan citra yang positif terhadap aksi 212. Data modalitas MI juga merepresentasikan citra yang positif terhadap aksi 212, citra positif tersebut juga diimbangi dengan representasi yang positif terhadap Joko Widodo yang hadir pada Aksi 212. Secara tekstual hal tersebut sejalan dengan judul pemberitaan masing-masing.

Perbedaan hasil analisis teks tersebut sejalan dengan analisis produksi teks dan analisis latar belakang sosiokultural-politik teks. Kedua analisis tersebut menunjukkan posisi masingmasing media. KS yang dipimpin Hary Tanoesudibjo dikenal dekat dengan Islam, hal itu sebagai upaya meraih dukungan muslim bagi partai Perindo. Sementara itu, MI yang tidak terlepas dari pengaruh sosiopolitik Surya Paloh lebih mengedepankan representasi Joko Widodo karena pendukung pemerintah dan pendukung Gubernur Basuki Cahaya Purnama (Ahok) yang (diduga) menistakan agama Islam.

\section{DAFTAR PUSTAKA}

Ahmadi F, Yusep. (2014). Analisis Wacana Kritis: Ideologi Hizbut Tahrir Indonesia Dalam Wacana Kenaikan Harga Bbm 2013 Di Buletin Al-Islam Yang Berjudul 'Menaikkan Harga Bbm : Menaikkan Angka Kemiskinan“.Metalingua Jurnal Penelitian Bahasa. 12 (2)hlm. 253268

Ahmadi F, Yusep. (2016). Analisis Modalitas Tuturan Basuki Cahaya Purnama (Ahok) dalam Wacana Kalijodo.Gramatika: Jurnal Ilmiah Kebahasaan dan Kesastraan. Vol. IV No. 2. hlm. 69-77. 
Atmaja, Xena Levina. (2014) berjudul “ Analisis Framing Terhadap pemberitaan sosok Basuki Tjahaya Purnama(Ahok) di Media Online". Jurnal E-Komunikasi. Vol.2 No. 1.

Ahsanu, Muhamad. (2013). Aceng's Unforgiven Apology: An Interdisciplinary Critical Discourse Analysis. Jurnal Kandai 9 (1)hlm. 36-48

Aminuddin, Ahsani Taqwim. (2017)."Instagram: Bingkai Kasus Agama di Media Sosial". Jurnal The Messengger. Vol.9. No. 2.

Mayasari, Silviana (2017) . Konstruksi Media Terhadap Berita Kasus Penistaan Agama Oleh Basuki Tjahaya Purnam (Ahok)", Jurnal Komuikasi. Vol. VIII No. 2. Hlm. 8-18.

Darmayanti, Nani dkk.(2011). "Pidato Politik Susilo Bambang Yudhoyono Sebagai Calon Presiden Republik Indonesia 20092014: Analisis Wacana”. Metalingua Jurnal Penelitian Bahasa. 9 (1), hlm.: 73-88.

Eriyanto.(2009). Analisis Wacana: Pengantar Analisis Teks Media. Yogyakarta: LKiS Yogyakarta.

Fairclough, Norman. (1992). Discourse and Social Change. Cambridge: Polity Press.

Fairclough, Norman.(2003). Analysing Discourse: Textual analysis For Social Research.London and New York: Routledge.

Fairclough, Norman. 1989. Language and Power. Cambridge: Polity Press.
Fairclough, Norman. 1992. Discourse and Social Change. London: Logman.

Fairclough, Norman. 1995. Media Discourse. London: Edward Arnold

Fairclough, Norman. 2003. Analysing Discourse: Textual analysis For Social Research. London and New York: Routledge.

Fiske, Jonh. (2012). Pengantar Ilmu Komunikasi. Jakarta: Raja Grafindo Persada.

Halliday, M.A.K. 1985. An Introduction to Functional Grammar. London: Edward Arnold.

Haryatmoko. (2016). Critical Discourse Analysis (Analisis Wacana Kritis): Landasan Teori, Metodologi dan Penerapan. Jakarta: Raja Grafndo Persada.

Santoso, A. (2012). Studi Bahasa Kritis: Menguak Bahasa Membongkar Kuasa. Bandung: Mandar Maju.

Santoso, A. (2008). "Jejak Halliday dalam Linguistik Kritis dan Analisis Wacana Kritis". Jurnal Bahasa dan Seni, Tanpa halaman.

Utomo, Wisnu Prasetya. (2013). Menimbang Media Sosial dalam Marketing Politik di Indonesia: Belajar dari Jokowi-Ahok di Pilkada DKI Jakarta 2012”. Jurnal Ilmu Sosial dan ilmu Politik. Vol. 17 No.1 th 2013. Hlm. 67-84.

van Dijk, Teun A. (1998). Ideology: $A$ Multidisciplinary Approach. London: Sage 
http://jlt-polinema.org/?page_id=275.

Analisis Wacana Kritis

Pemberitaan "Saweran untuk

Gedung KPK" di Harian Umum

MMI. Jurnal Linguistik Terapan

Vol. 2/2. Politeknik Negeri

Malang. Diakses 10 Februari, 2017

https://partaiperindo.com/?page_id $=6$.

Profil Partai Perindo. Diakses 15

Januari, 2017

http://onierbana.blogspot.co.id/2015/10/

media-profile-koran-sindo-mediacetak.html. Media Profile Koran

Sindo (Media Cetak). Diakses 20

Januari, 2017

http://mediaindonesia.com/about-

us.Profil Media Indonesia.Diakses

20 Januari, 2017 
Kandai Vol. 15, No. 1, Mei 2019; 1-12 